\title{
Crime Assessment in Cyprus during the Period 2003-2013 and Identification of the Main Causes
}

\author{
By Markianos Kokkinos
}

This paper explores crime rates in Cyprus during the period 2003-2013 and identifies the main factors causing crime tendencies. Criminal statistics, based on official police recorded data, show divergent trends, as a result of the several events taking place concerning the economy, the political and social life, not only in Cyprus but worldwide. Apart from the legislation changes and the introduction of new laws, these events are especially the opening of the crossing points in the UN-patrolled buffer zone separating the Turkish-occupied northern part of Cyprus from the free areas of the Republic of Cyprus in 2003, the accession of Cyprus in the European Union in 2004 and the global economic crisis that appeared in 2009. Even though there are different tendencies for specific types of offences, in general recorded crime in Cyprus gradually increases reaching the peak in 2011. The patterns in crime reflected by the socio-economic factors are a warning of the change of Cyprus' small society and a challenge to policy makers in the mission of crime prevention.

Keywords: Crime, Criminality, Cyprus, Factors, Trends.

\section{Introduction}

Crime is a social problem that has long been a research concern for many scientists, including statisticians, who are trying through their work to find methods to prevent or reduce it. Due to the complex, sophisticated, technologically advanced and internationalised dimension crime is taking, the need for cooperation in order to combat crime, has already been identified in the past (Tsiamtsiouri and Panaretos 1999). The several events that take place worldwide concerning the economy, political and social life, activated a motion against the security order and particularly the European security order (Carr 1996, Sperling and Kirchner 1997, Hebenton and Spencer 1999). As analysed by Aebi (2004), crime opportunities are strongly affected by numerous social and economic factors.

The various crime levels call for end results and practises, in order to promote and ensure the societies' security and safety and contribute to their sustainable development (UN 2005). Governmental authorities are greatly dependent on crime development, as a lot of pressure is put on imposing justice laws. Thus, the challenge to decision and policy makers in determining strategies and interventions is the ability to examine crime trends and understand the main factors causing crime.

\footnotetext{
*Open University of Cyprus, Cyprus.
} 


\section{Rationale}

Even though several governmental annual crime reports exist that present mainly data on crime trends and comparisons with previous years, it is rare to find reports with evaluated and justified results. It is essential for governmental and local authorities to have studies with recommendations and results to help them modify policies, interfere and fight crime (Blumstein 2002). As far as the case of Cyprus is concerned, apart from few individual studies, crime has not received enough scholarly attention and little is still known, since no official research has been carried out in depth. The lack of studies and sources of information on the one hand and the need for empirical data, end results and practises for preventing criminal acts on the other, have initiated this project work.

In fact, this project work presents, evaluates, explains and justifies crime trends in Cyprus during the period 2003 and 2013, by identifying the main factors causing these tendencies. While official police data concerning the recorded offences are being demonstrated using trend lines and descriptive statistics, the various social, political and economic factors and events taking place in Cyprus affecting crime rates are identified and validated, in respect to the divergent trends observed in crime levels. New cultural and socioeconomic characteristics reflect the patterns and distribution of criminality (Hadjidemetriou 1995). The originality of this study is supported by the recognition of these main socio-economic factors interacting with crime in Cyprus.

Despite the shift towards the fight and prevention of criminal acts, data concerning crime is still unreliable and not as accurate as expected. Even harder is the comparison of crime data among countries; sometimes it is even considered impracticable (Killias and Wolfgang 2000). Misinterpretation or misuse of police statistics is also visible and may result from the analysis of crime data, as this is based on police reports which actually do not represent the reality in total and all crimes occurring in a society, but only the crimes reported to the police and those identified by control activities of the police itself (Boba 2005). Recent wrong crime forecasts doubt the potentials to interpret official crime statistics and correctly appreciate the factors impacting crime (Buonanno et al. 2014). In addition, crime data captured by police agencies is dynamic and not static, since information about crime incidents is constantly being updated depending on the investigation procedures and availability of information. Finally, a rival factor that should also be carefully considered in the statistical interpretation of crime is the point of time an offence is committed, as it is not always possible to know the exact date or time of a criminal act. Even in cases where police recorded statistics show a decrease in crime rates, the perception of locals could be opposing (Pfeiffer et al. 2005).

As the emphasis of this article is on studying and identifying patterns of crime in Cyprus and trying to explain whether these are caused by specific factors, it is essential prior to any analysis to present the policing situation and crime recording system in Cyprus. 


\section{Law Enforcement and Policing in Cyprus}

Among the ambitions and tasks of Cyprus Police is the implementation of strategies for preventing crime as well as other protective and legislative measures, originated from the national legislation, EU directives, international treaties and police co-operations, in order to face the various types of crime, anti-social behaviours and phenomena (Cyprus Police n.d.).

However, as a result of the illegal Turkish invasion of the island in 1974 and the unlawful military occupation of the north part of the island, counting about $37 \%$ of the territory, Cyprus Police can exercise its power only in the remaining areas $(63 \%)$ under the effective control of the government of the Republic of Cyprus. Additionally, after the accession of the Republic of Cyprus into the European Union in 2004, Cyprus Police had to undergo further administrative changes as it additionally had to work for the security and safety of Europe in general and not only for Cyprus alone.

Based upon the provisions of the law, international agreements and the relevant conventions, no organized criminal groups can be identified in Cyprus. Indeed, no criminal activities meet all four mandatory criteria as well as the secondary criteria provided by the European Union in order to be classified as "Organized Crime"1.

Offences in Cyprus, based on the Criminal Code, are firstly classified into two categories: "serious" and "minor" depending on the importance of the offence and the level of penalty, according to the Law (CYSTAT 2014). Further classification is based on the grouping of offences into several categories as it appears in the Criminal Code. The standard counting units used are the offence/case as well as the number of offenders. In cases where an offender is involved in more than one offence only the most serious case is recorded/counted.

Comparisons across countries are problematic as the offence definitions and justice systems vary. In addition, as argued by Santana et al. (2009), higher numbers of recorded crimes may also reflect the society's maturity and citizen's trust levels in reporting criminal behaviour and not only the actual crime levels. Even within a country, comparisons should be made with the assumption that the characteristics of the recording system remain fairly constant over time. However, changes in the definition of an offence and the inclusion of new offences are not rare, thus making comparison difficult. Cyprus' criminal justice system is not an exception and several changes did take place over the last years. The most important modification occurred in 2003, when a change in the recording practice of serious offences reported to the police resulted in a much higher number of cases recorded (CYSTAT 2014). Therefore, for consistency reasons, this study evaluates crime levels in Cyprus from 2003 and onwards, by carefully addressing any trend breaks.

\footnotetext{
${ }^{1}$ The four characteristics that must be present, for any crime or criminal group to be classified as organised crime are: 1) Collaboration of more than two people; 2) For a prolonged or indefinite period of time (this criterion refers to the stability and (potential) durability of the group); 3) Suspected of the commission of serious criminal offences; 4) Determined by the pursuit of profit and/or power.
} 


\section{Literature Review}

One main concern for many policy makers, when evaluating a country's development, is the crime rate. In recent years, many practitioners and researchers try to appraise the impacts from a broader range of socio-economic factors. The phenomenon though is unexpectedly compound and multifaceted as the conclusions do not always concur, whereas in some cases conflicting findings or speculations have been reported. Moreover, the factors recognized in each study vary depending on the case under study, concluding that they have dissimilar impacts in different countries, whilst in some it is not possible to reach final conclusions as there is not enough evidence.

A large amount of the research concerning crime rates refer to the United States, as in the 1970's the levels of crime in the United States were much higher than elsewhere (Buonanno et al. 2011). Their analysis though pointed out that since then, the levels of crime in Europe increased to even higher levels. In their study, it was recognized that the primary factors impacting crime trends were the rates and figures on demography, immigration, unemployment, abortion, and incarceration.

As identified by many studies age, gender, and race are determinants of a potential offender's profile (South and Messner 2000, Blumstein and Wallman 2006, Hartnagel 2009). The rise or decline of the rates of several types of crime is highly related to demographic characteristics (Steffensmeier et al. 1989). In particular, it is pointed out that ageing populations are less likely to be involved in criminal acts. As explained by Steffensmeier and Harer (1991), the fluctuation of crime in the United States during the late 20th century is highly related to the changing age composition of the American and Canadian populations. As race is concerned, Sampson and Lauritsen (1997) have related homicides in the United States with race and the changes in racial composition. An examination of the relationship between socio-economic misfortunes and crime, by focusing on violent crime by African Americans, suggested that an analysis considering cultural factors will be beneficial in explaining crime trends (Latzer 2018). There is also an acknowledgement that the mechanisms underlying the development of offending may differ depending on ethnic and/or cultural backgrounds (Piquero et al. 2015, Jolliffe et al. 2016).

Apart from demographical changes, other factors and variables should be considered in evaluating crime (Fox and Piquero 2003). LaFree (1999) recognised that issues like economic stress, family and lifestyle changes, drugs, policing initiatives, incarceration, education and welfare affect the opportunities for crime. Fazel et al. (2015) have demonstrated that depression is positively related to delinquency while Jolliffe et al. (2018) concluded that depression and anxiety were outcomes of offending. An extensive amount of research pointed out the association between mental health problems and delinquency (Hein et al. 2017, McCormick et al. 2017). As mentioned by Joyce (2018), there is no single explanation of why people commit crime. Beyond the main psychological, biological and sociological explanations pointed out, elements of historical and political analysis should be considered. 
Several other reports explore and focus their analysis on the interaction of economic factors with specific types of crime. It is believed that opportunities for organised crime may increase due to the economic crisis, whereas cyber crime is also expected to rise during the economic recession (ICPC 2010). An increase in unemployment could also have significant implications for increasing criminalisation. A small but statistically significant relationship was identified between unemployment rates and property crime (Donohue and Levitt 2001, Raphael and Winter-Ebmer 2001). It is identified that crime is higher in areas with lower income people. As analysed by Merlo (2003), the inequality in wages is positively correlated to the crime rate.

Changes in policing with the implementation of new laws or strategies like "community policing" and the use of technology in crime mapping have been considered in exploring crime trends, but as discussed in Wilson (1985), it is rather difficult to measure and conclude that they have lowered crime. Even though a typical approach in fighting crime is to increase the number of police officers, the survey of Cameron (1988) could not support a relationship. On the other hand, Marvell and Moody (1996) concluded that higher numbers of police officers are linked with the drop of crime. Similarly opposing conclusions are reported for the concealed weapons laws and their appreciable impact on crime dimensions (Black and Nagin, 1998, Duggan 2001, Ayres and Donohue 2003).

The effectiveness of increased punishment to lower crime rates and in particular the use of the death penalty as a deterrent has been examined and discussed for decades, with opposing opinions and end results (Forst et al. 1978, Cameron 1994). According to Levitt (2004) the increased imprisonment to reduce crime is effective, as offenders are less able to commit further crimes while incarcerated, whereas future criminals are discouraged from committing one.

Evidence presented by some reports suggests the positive consequences of the legalisation of abortion in reducing crime rates, as the unwanted births and children who are at greater risk for crime are minimised (Dagg 1991, Stolley 1993).

As identified by the literature review, several causes are accountable for crime trends, depending on the occasion and period of time. This research study attempts to evaluate some of these factors as they appear for the case of Cyprus.

\section{Research Methodology}

As identified in the literature review, the reliability of official crime statistics and the factors influencing criminal acts may be questioned (Buonanno et al. 2014), while the willingness of victims to report crime, the administrative procedures, the changes in the recording practises and definitions may also account for the unstable tendencies of crime rates (Cook and Khmilevska 2005). However, a cautious approach through descriptive and inferential examination has been accepted by many researchers in this field (Aebi 2004, Dills et al. 2008, Goldberger and Rosenfeld 2009).

In an effort to get insights in the crime levels in Cyprus, the analysis of this 
study is based on the official Cyprus Police statistics, while reviewing publications in key areas of criminology. The necessity of police statistics for analysing and comparing crime trends over time, as long as recording methodologies and legal definitions remain constant, is recognised (Aebi 2004). Police data used in this project refer to the years from 2003 onwards, since previously there was a significant change in the crime recording practices within Cyprus Police.

Even though crime rates are believed to be proportionate to the population rate, an in-depth analysis of crime data based on the per 100,000 population index rate is avoided in this report. Such analysis and comparison could be misleading for the case of Cyprus due to the large number of tourists visiting the island and their unspecified duration of stay, the several investors, workers and students, as well as the unknown number of illegal immigrants present. Cyprus, a country traditionally exporting migrants has been transformed into one that is hosting migrants (Trimikliniotis 1999). Likewise, the lack of any local estimates of the size of the dark figure of crime not reported to the police is an additional justification. Even though criminological and criminal justice research is a relatively new academic discipline in Cyprus, the findings on delinquency and victimization gathered from self-reported surveys suggest higher rates of delinquency than those based on official statistics (Kapardis 2013). In general, Cypriots do not report crimes and victimization to the authorities because they believe it would implicate them socially and personally (Hadjidemetriou 1995). Consistent are also the results of a victimization survey concluding that some victims in Cyprus did not report the crime to the police as they did not believe in the police's ability in clearing their case (Zalaf and Wood 2009). Therefore, since only the case of Cyprus is examined and no comparisons are made with other countries, the absolute crime figures are used instead of the rates of offences per 100,000 populations.

The best way of describing and summarising data relies on descriptive statistics (Hinton 2014). This is based on the distribution of the data and can indicate its main characteristics. The measures of central tendency, like the mean value, give a brief description and comparison of the available data. The dispersion measures, like the standard deviation (SD), provide a picture of the concentration of the observations in a data set (Agresti 2017). Along with the mean and standard deviation values, the maximum and minimum values as well as the coefficient of variation $(\mathrm{CV})$ are also used in the analysis of this period under consideration, to objectively verify the findings and trends observed. Through the whole research work, quantitative data is analysed, interpreted and presented aided by graphs and charts in an effort to capture all the details and meaning of the data, while reliability and validity issues are strongly considered. The project's methodology is also based on a triangulation framework. Following the extensive literature review and investigation, crime data and information from other sources, such as Eurostat and the European Sourcebook of Crime and Criminal Justice Statistics (ESB), are also considered in an effort to establish the correctness of the findings.

Based on the literature review and previous studies, some of the composite factors affecting crime rates have been identified. These have been considered and carefully approached as they appear for the case of Cyprus, under the assumption 
that other factors remain constant and no interactions or other effects are present. Similar to other studies, information on the demography, immigration, unemployment and incarceration were also used for determining crime development. Finally, the results are presented and discussed relating them to the reported descriptive statistics.

\section{Findings and Analysis}

Considering that the population of Cyprus in 2013 was 858,000 (CYSTAT 2015) and only 7,089 cases of serious crime were reported, it can be suggested that criminality in Cyprus is kept at low levels. The majority of the criminal acts and behaviours concern mainly offences against property such as thefts and burglaries (Cyprus Police 2015). Indeed, according to ESB statistics (Aebi et al. 2014), while the mean number of offences per 100,000 inhabitants among 35 countries of Europe in 2011 was 4,513, the corresponding value in the case of Cyprus was only 1,003 . Even though it is unsafe to fully rely on comparisons across countries, as the definitions of legal concepts differ and the recording and presenting methods vary, the difference in these values is big enough to conclude that on a comparative level the rate of crime in Cyprus can be described as low.

As seen in Figure 1, the total number of criminal offences recorded by the police in Cyprus between 2003 and 2013 (Mean=19,550, SD=1576), indicates a slow but steadily increasing trend, starting from 17,741 recorded cases in 2003 and reaching the maximum of 22,758 cases in 2011 , followed by a sudden decrease to 17,893 cases in 2013. Also supported by Tavares and Thomas (2009) in a report of Eurostat, there seems to have been an increase in crime between 2002 and 2008 in Portugal, Slovenia, Italy, Spain and Cyprus, opposing the downward general national trend in most countries in the EU after 2002. Additionally, according to ESB statistics (Aebi et al. 2014), while the rate of crime in 20 countries in Europe has decreased from 2007 to 2011, the rate in Cyprus is among those 13 countries that have increased. As accepted by Gruszczyńska and Heiskanen (2012), crime trends are different in various areas.

Observing separately the trends of serious and minor crime in Cyprus (Figure 1), it can be identified that the increasing trend in total crime results mainly from the upward trend in minor crime. This is explained by the fact that minor crime accounts for approximately $60 \%$ of the total crime. In particular minor crime (Mean=11,920, SD=1218), increased from 10,460 cases in 2003 up to the maximum of 14,332 cases in 2011 , followed by a sudden decrease to 10,804 cases in 2013. Serious crime, which is kept at a lower level (Mean=7629) seems to be more stable, with less noticeable fluctuations along the same period ( $\mathrm{SD}=486)$. This is also verified by the coefficient of variation $(\mathrm{CV})$, which for serious crime it is estimated to be $6.4 \%$, much lower than that of minor crime with $10.2 \%$. The peak was again recorded in 2011 with 8426 cases. According to this result, it can be stated that the year 2011 was the one with the highest criminality rate in Cyprus. Evidence of this increase is as well the fact that the prison population (at 1 September) doubled from 355 in 2003 to 694 in 2012 
(Eurostat 2014), consistent with the argument that a higher criminality rate leads to a higher rate of imprisonment (Mauer 2003).

Figure 1. Police Recorded Offences for the Period 2003-2013

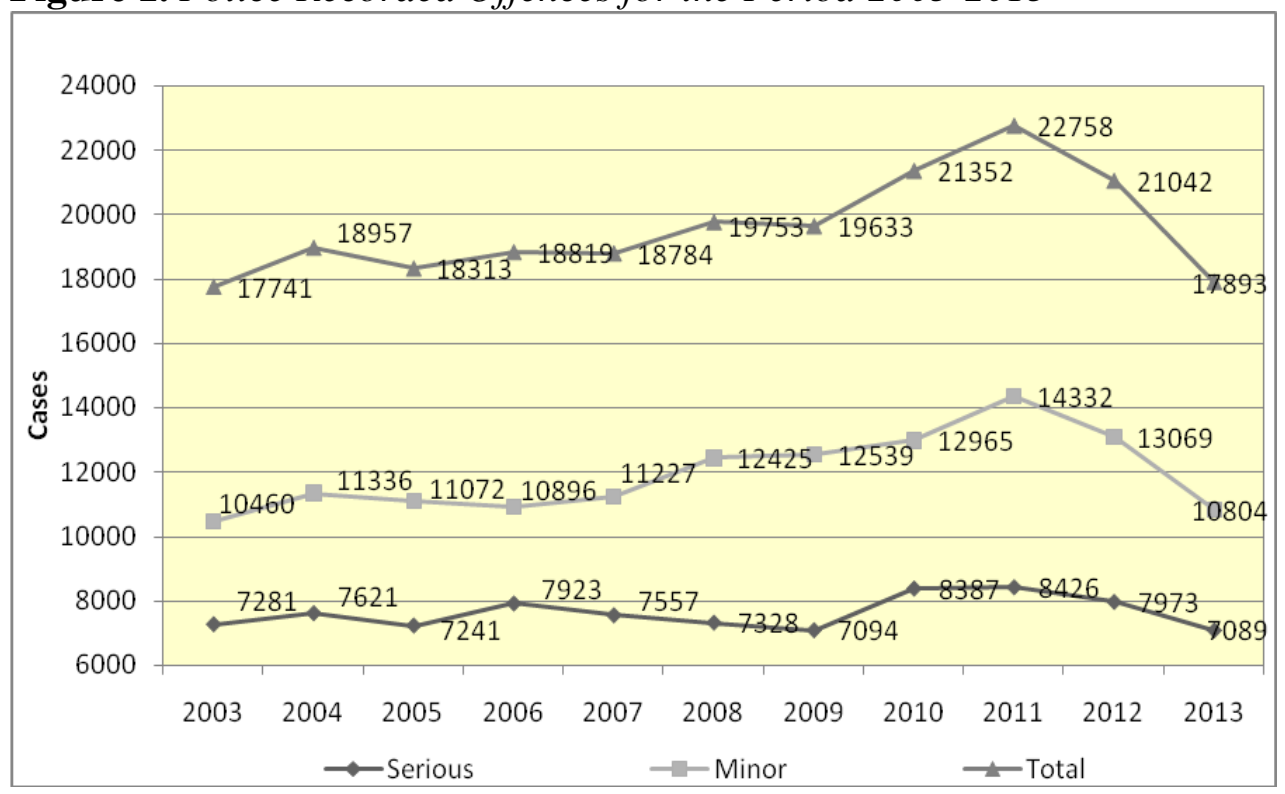

As this study tries to evaluate and identify the possible factors which are believed to play an important role for the fluctuation in various types of crime, the several socio-political and economical changes which have occurred in Cyprus during the last decade are examined in the following subsections.

\section{Opening of the Crossing Points}

First, in chronological order, is the opening on 23 April 2003 of the crossing points in the UN-patrolled buffer zone separating the Turkish-occupied northern part of Cyprus from the free areas of the Republic of Cyprus, known as the "green line" and the potential movement of people throughout the whole island. Even though all Cypriots belong to the European Union family, its laws as well the laws of the Republic of Cyprus cannot be implemented in the occupied northern areas of Cyprus, as this part is only recognised by Turkey. That is why both GreekCypriot and Turkish-Cypriot victimisers and serious crime offenders such as murderers and rapists make full use and benefit from this situation by finding a place to hide in the occupied northern part of the island, thus escaping from justice. The increasing figures in the police statistics are considered to be related with this fact.

Moreover, various cases and media articles also support this. For instance, the persons arrested in the occupied northern areas for the triple murder on a highway in the free areas of the Republic of Cyprus on January 15, 2005, were not sent to custody but released and let free in both Turkey and the northern occupied areas of Cyprus (Cyprus Mail 2018). Referring to the five Iraqis who in 2008 were badly injured by a landmine while attempting to cross the "green line", BBC News 
(2008) revealed: "The five, including a child, were in a group thought to have been smuggled to the island to claim political asylum".

As a result of the opening of the "green line" the smuggling of drugs and illegal substances from the occupied northern areas to the free areas of the Republic of Cyprus also became easier. Likewise, the number of reported cases related to drug offences (Mean=768, SD=191) increased from 475 cases in 2003 to 1001 cases in 2013, with the peak being recorded in 2012 with 1032 cases (Figure 2). Despite the strict and hard punishments for drug related offences including those of importation and sale, the quantity of drug substances seized by officials such as cannabis, cocaine and heroin keep increasing.

Figure 2. Police Recorded Drug Offences for the Period 2003-2013

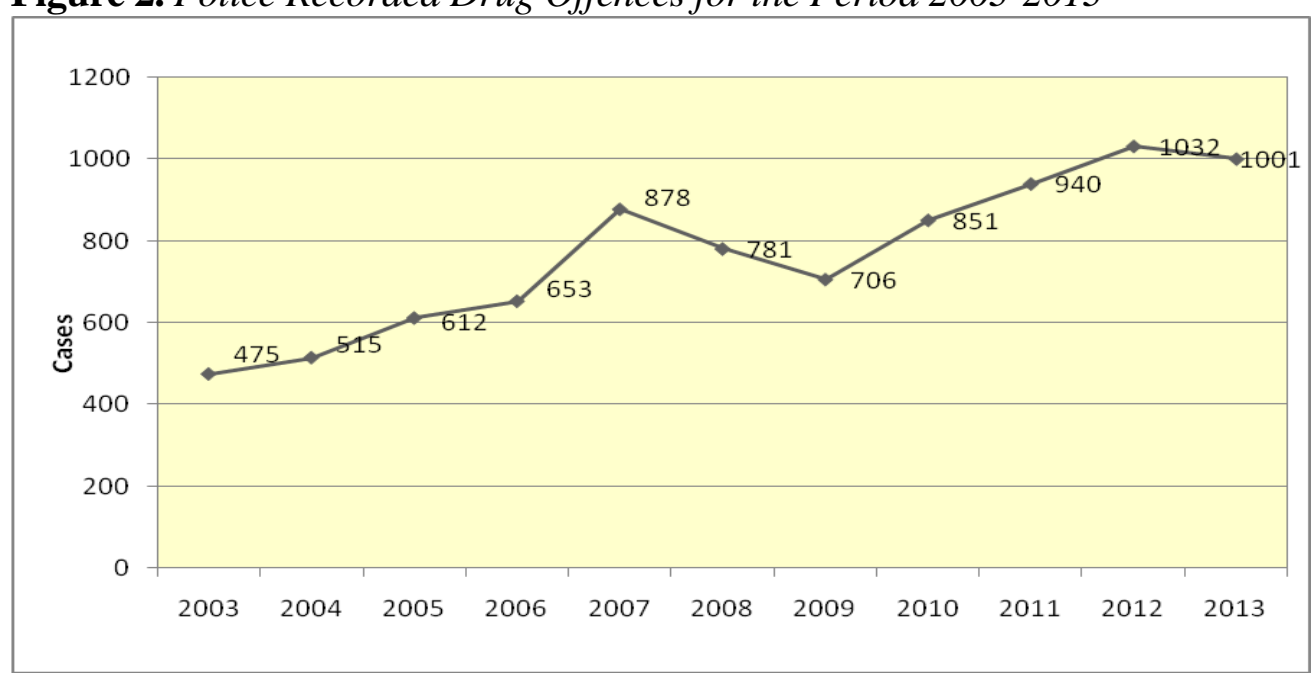

\section{Global Economic Crisis}

As of 1990, Cyprus has experienced large scale immigration mainly due to the increment of labour opportunities (Gregoriou et al. 2010). Despite the benefits gained from migrant workers and the increasing trend of moving across within international borders, the impact of migration on safety and crime has been under serious concern. Specifically, the number of illegal immigrants arriving from the occupied northern area is a phenomenon that troubles the country's society in general. The rates, though, as displayed in Figure 3 tend to decrease, especially from 2009 onwards, indicating a drop in the motivation of foreigners to immigrate to Cyprus for employment. The big change in figures before and after 2009, resulted in SD value $(1,157)$ higher than the mean value $(1,012)$. The overall drop in the trend line could be attributed to the global economic crisis that appeared in 2009 , resulting in a rapid increase of the unemployment figures from 21,000 in 2009 to 69,000 by the end of 2013 and hence fewer opportunities for work (CYSTAT 2016). 
Figure 3. Number of Illegal Immigrants from the Northern Occupied Area Applying for Asylum for the Period 2003-2013

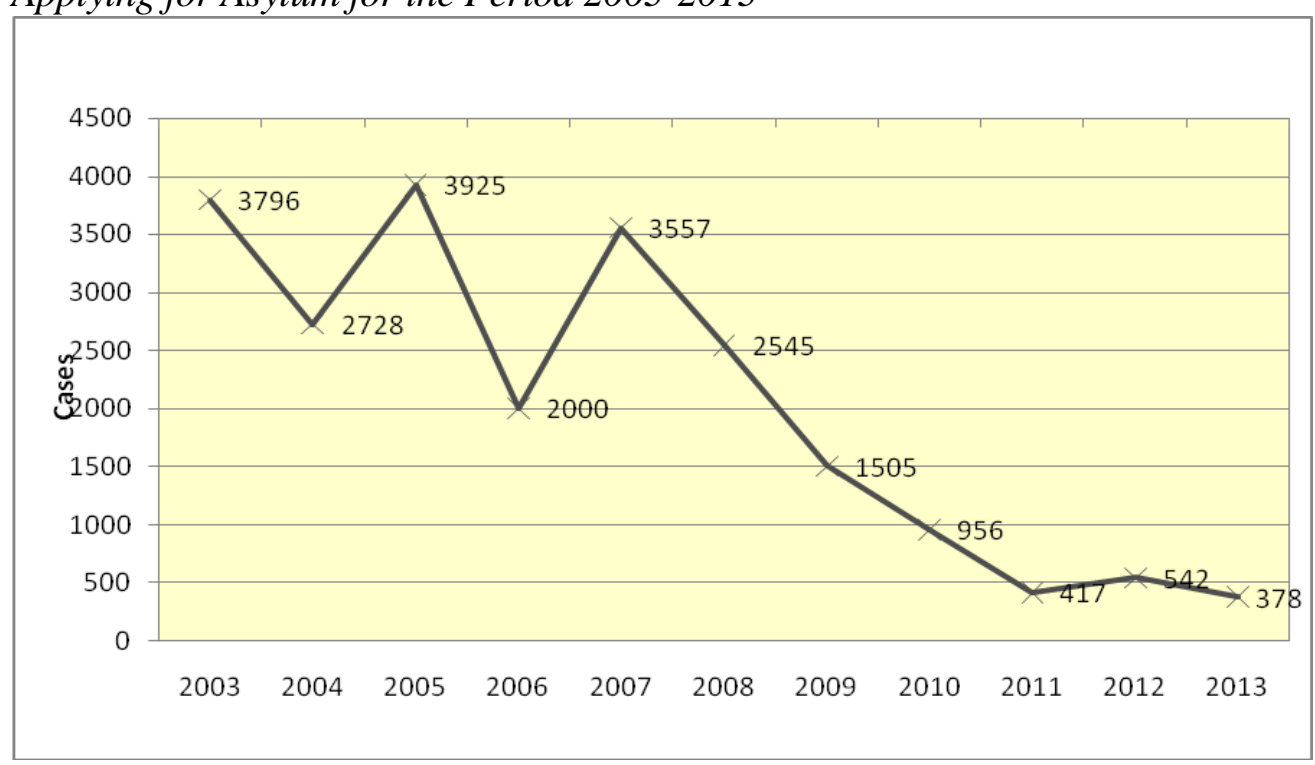

The global economic crisis with the above mentioned consequences on migration and unemployment, as appeared in 2009, could also be among the main causes for the fluctuation in several types of crime (Figure 4). For this, the absolute values and trend lines of the most common serious offences are examined. Specifically, the crimes of burglaries and housebreakings, thefts of items with a value of more than $€ 1000$ and forgeries are considered.

Figure 4. Tendency for the Most Frequent Serious Offences for the Period 20032013

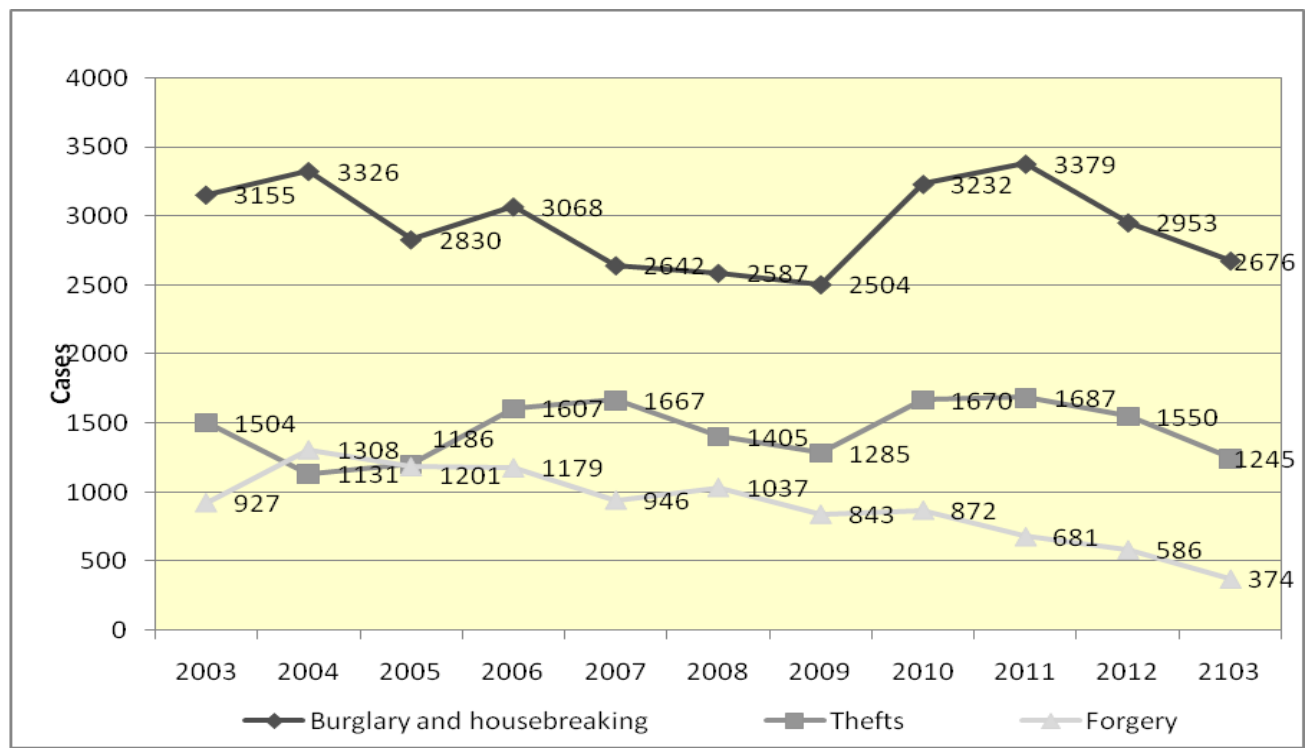

Concerning the most frequent serious offences in Cyprus, which are burglaries and housebreakings (Mean=2,941, SD=312), as well as thefts of items with a 
value of more than $€ 1,000$ (Mean $=1450, S D=206$ ), these incidents peaked after 2009 reaching the maximum in 2011 with 3,379 and 1,687 cases respectively. In both cases, these recorded values in 2011 are approximately 15\% higher than their mean values. Differently, for forgeries (Mean=904, SD=278) there is a gradual fall from 1,308 cases in 2004 to 374 in 2013. Comparing the trend lines and dispersion among the three above mentioned serious offences, it is found that the highest variability is in forgeries with a CV of $30.8 \%$, compared to $14.2 \%$ for thefts and $10.6 \%$ for burglaries and housebreakings.

As for other equally important, but less frequently committed serious crimes, like robberies, an upward shift is also reported, from 69 cases in 2003 to 149 in 2013, recording an increase of 116\% (Cyprus Police 2015). For homicides, the variation in the pattern throughout the years is high and unstable, ranging from 7 to 19 murders per year.

Figure 5. Tendency for the Most Frequent Minor Offences for the Period 20032013

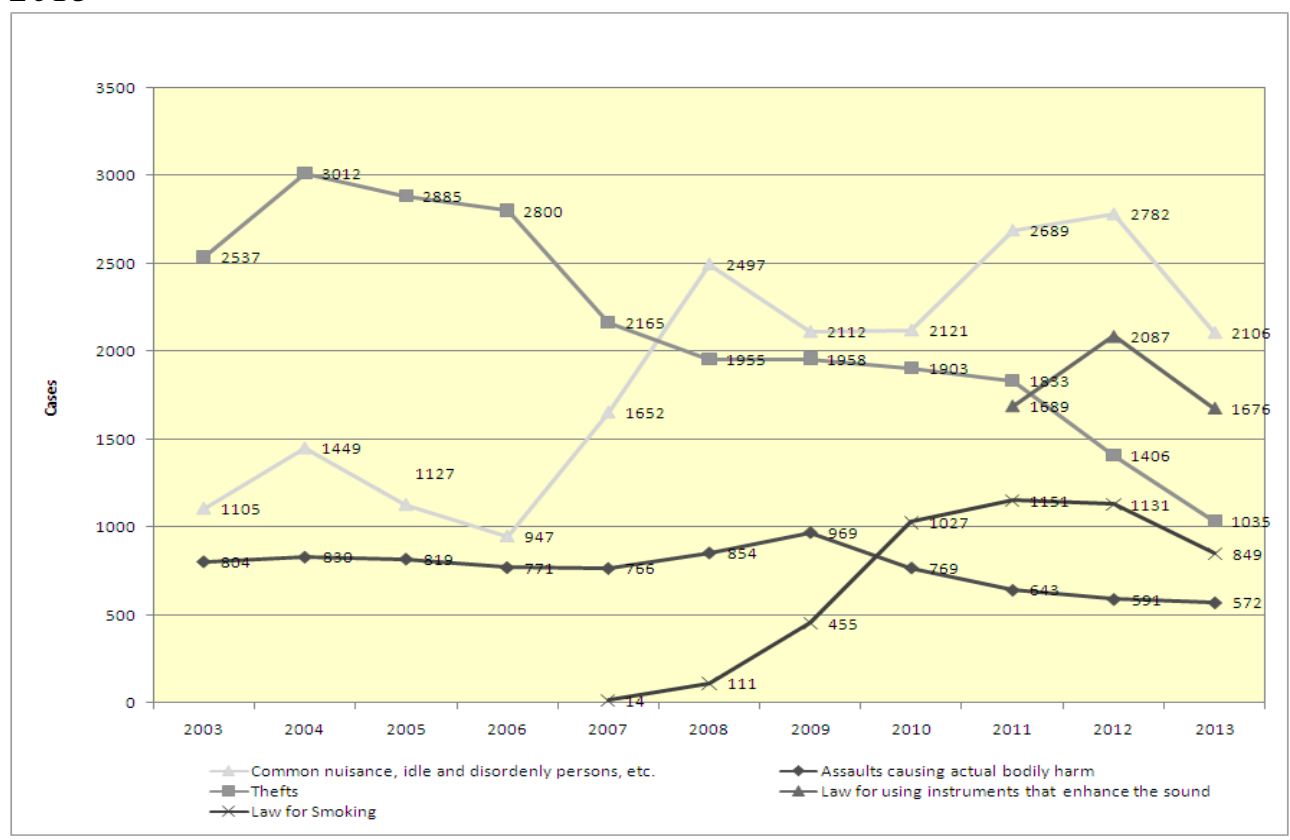

Concerning minor crime though (Figure 5) and the most frequently committed offences, those against property like theft (value up to $€ 1,000$ ) and offences against public in general like "common nuisance, idle and disorderly persons", no interaction has been identified with the factor of the global economic crisis, even though there is a steady decrease. Specifically, for thefts (value up to $€ 1,000$ ), the maximum was recorded in 2004 with 3102 cases, followed by a gradual decrease reaching the minimum in 2013 with 1035 cases. For the overall period, the mean number of thefts is calculated to be 2135 with a SD of 623 and a CV of $29.2 \%$. As for "common nuisance, idle and disorderly persons", the pattern is unstable. The evolution recorded in the period 2006-2008 was followed by a temporary drop to 2112 cases in 2009, increased again to 2782 cases in 2012 and declined again to 2106 cases in 2013. These frequent fluctuations resulted in a very high CV of 
$67.1 \%$ (Mean=1232, SD=826). On the other hand, assaults causing actual bodily harm have remained virtually unchanged the years before 2009 with no important variations, followed by a steady decrease to 572 cases in 2013. As a result, the CV for assaults is estimated to be $15.5 \%$, which is much lower than that of thefts (value up to $€ 1,000$ ) and "common nuisance, idle and disorderly persons".

As also identified in the ESB (Aebi et al. 2014), a trend in recorded crime is not the same among the several types of offences. Despite the failure of relating the trends of all types of minor crime to the economic crisis in Cyprus, the detailed examination pointed out another factor, namely the "Introduction of new laws" as described below.

\section{Introduction of New Laws}

As also suggested by Clark (2013) in a Eurostat report, the change in the frequency of committed offences could be affected by new policing strategies or changes in the methodology. Similarly, in Cyprus, a main reason of the increase in minor crime over the last decade seems to be the induction of new offences based on the initiation of recent laws, together with the organised campaigns and intensive efforts by the police for implementing these laws. Specifically, as seen in Figure 5, the amendment of the Law for smoking in 2010, for preventing smoking in public places (restaurants, clubs etc.) has more than doubled the recorded cases from 455 in 2009 to 1027 in 2010 . Similar is the case with the introduction of the Law for "using instruments that enhance the sound without authorization or in breach of permit conditions", with 1689 cases being reported in 2011, 2,087 cases in 2012 and 1,676 cases in 2013.

\section{Accession of Cyprus in the European Union}

Cyprus suffered massive population shifts following the accession in EU in 2004 and the movement of EU residents across EU countries, together with the phenomenon of immigration (legal or not). This has contributed not only to the reclassification of the population of the island but also of crime as well. Consistent with the survey analysis in Switzerland (Eisner and Killias 2004), the change in the ethnic composition of offenders is causing considerable shifts.

Based on the cases recorded and detected by the police, as seen in Figure 6, it is obvious that the involvement of non-Cypriot citizens in total crime is constantly rising. 
Figure 6. Involvement of Cypriot and non-Cypriot Citizens in Total Crime for the Period 2003-2013

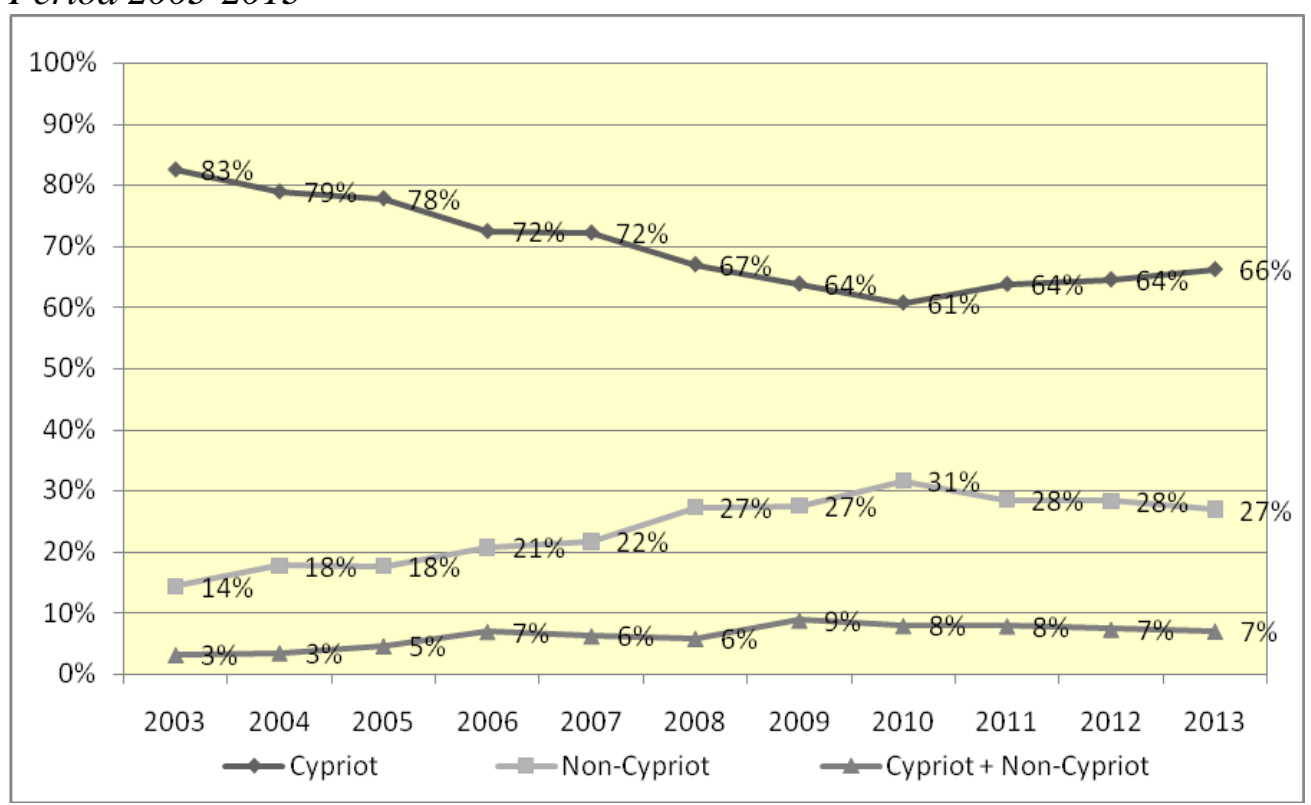

In 2003, non-Cypriots counted for $14 \%$ of the total detected cases reaching $27 \%$ in 2013 . The maximum proportion (31\%) was recorded in 2010. Moreover, in 2010, the maximum percentage of aliens among the offenders in the EU countries was recorded in Cyprus (Aebi et al. 2014). At the same time the proportion of Cypriot citizens continued to decrease from $83 \%$ in 2003 to $66 \%$ in 2013. The proportion of cases in which both Cypriots and non-Cypriots were involved ranges at lower levels, from $3 \%$ to $9 \%$. Additionally, due to the free movement across EU countries, few itinerant criminal groups claiming to be tourists were discovered while committing crimes against property like thefts (Kokkinos and Kapardis 2015). As also discussed by Brunt et al. (2000), in some cases the purpose of travelling is unrelated with holidays.

\section{Conclusions}

The phenomenon of crime is characterised by perplexity and complexity and is thus difficult to measure due to its secretive nature and the long lasting procedures needed for reporting and investigating crime and bringing an offender before the criminal courts. Recorded crime in Cyprus kept increasing until reaching the peak in 2011, with rising drug and property offences as well as several 'minor' offences. Even though organized crime cannot yet be identified in Cyprus, there is evidence for a link with organised groups outside the country. This, together with the demographic changes of the island's population, could be considered as a warning for a change of Cyprus' small, closed and traditional society to a bigger and more multicultural one. The small size of Cyprus, though, was a challenge for this study, as it is identified that for analyzing such small populations extra caution should be given, since they are vulnerable to minor 
changes (Aebi and Linde 2010). Still, the methodology used and the overall agreement between the data presented in this study with the data from the various other sources have ensured the quality and reliability of this research work.

Considering that crime nowadays emerges in more complicated and advanced forms, the absence of specialised studies in the area of crime for the case of Cyprus, together with the absence of any local estimates of the size of the dark figure of crime in general is a weakness in the mission of crime prevention. Hence, there is an urgent request for more research work in this field in order to prevent and reduce crime. A key challenge for policy makers is the effective investigation and measure of crime trends and evaluation of the major driving factors.

Apart from the global economic crisis in 2009 and the negative impacts on the country's economic status, some other political and social changes have been identified and described in this report as the main causes of the trends in crime in Cyprus; namely the opening of the "green line" in 2003, the accession of Cyprus into the EU in 2004 and the initiation of new laws. These events were included and approached without implying that these are the only ones that affected crime trends. The limitations under which the phenomenon was studied were well acknowledged and reported prior to the findings.

The empirical work of this study is believed to initialise more investigations and research with further results, by considering other relevant determinants or extensions of the problem under study, such as the degree by which each identified factor drives and impacts patterns of crime. It is a great benefit for decision makers to recognise which factors cause crime and the level at which they are interacted, in order to know how to better alter policies and action plans for mitigating crime determinants and decreasing crime rates.

From the existing bibliography it is identified that countries' crime rates respond to different factors and also differently to each factor. Thus, the results of this project work cannot wholly be applied to other countries, while also some of the identified factors and events took place only in Cyprus. It is also pointed out that these factors recognised were evolved from the analysis only of the period under examination, namely 2003-2013. Other aspects and potential causes that are linked to delinquent behaviours should be considered to explain the reasoning criminal. According to Scott (2014), the assumption that rewards and punishments influence our choices of behaviour underlies economic, sociological, psychological, and legal thinking about human action.

As most of the researches and reports in Cyprus have so far been restricted on presenting only crime trends, this study, which identified causes and factors, is an innovating report for the country's police and criminal justice system. The findings of this article are believed to provide extra information in understanding crime levels, predicting crime rates and supporting policing practises, since from now resources and coordinated efforts against crime can better be allocated and aimed at. Moreover, it is believed that they further add to results and help to answer questions in the criminology area, not only for the case of Cyprus, but worldwide, as crime has no boundaries and cannot be restricted within one area only.

Regardless of the increasing crime trend observed in the period under examination, it is pointed out that Cyprus' criminality rate is among the lowest in 
EU, indicating that Cyprus is still a safe place to live in. Moreover, the drop of crime figures in 2012 and 2013 is promising for the future.

\section{References}

Aebi MF (2004) Crime Trends in Western Europe from 1990 to 2000. European Journal on Criminal Policy and Research 10(2-3): 163-186.

Aebi MF, Linde A (2010) Is there a crime drop in Western Europe?. European Journal on Criminal Policy and Research 16(4): 251-277.

Aebi MF, Akdeniz G, Barclay G, Campistol C, Caneppele S, Gruszczyńska B, Harrendorf S, Heiskanen M, Hysi V, Jehle JM, Jokinen A, Kensey A, Killias M, Lewis CG, Savona E, Smit P, Porisdottir R (2014) European Sourcebook of crime and criminal justice statistics $-20145^{\text {th }}$ edition, Helsinki: HEUNI.

Agresti A (2017) Statistical Methods for the Social Sciences. $5^{\text {th }}$ ed. University of Florida: Pearson.

Ayres I, Donohue J (2003) Shooting down the 'More Guns, Less Crime' hypothesis. Stanford Law Review 55(4): 1193-1312.

BBC News (2008, December 5) Iraqis wounded by Cyprus landmine. Retrieved from https://bbc.in/2HDANKP. [Accessed 18 December 2009].

Black D, Nagin D (1998) Do 'Right-to-Carry' laws deter violent crime? Journal of Legal Studies 27(1): 209-19.

Blumstein A (2002) Crime Modeling. Operations Research 50(1): 16-24.

Blumstein A, Wallman J (2006) The crime drop and beyond. Annual Review of Law and Social Science 2(1): 125-146.

Boba R (2005) Crime analysis defined. In Crime analysis and crime mapping, 5-18. Thousand Oaks, CA: Sage.

Brunt P, Mawby R, Hambly Z (2000) Tourist victimisation and the fear of crime on holiday. Tourism Management 21(4): 417-424.

Buonanno P, Drago F, Galbiati R (2014) How much should we trust crime statistics? A comparison between UE and US (No. 19). LIEPP working paper.

Buonanno P, Drago F, Galbiati R, Zanella G (2011) Crime in Europe and in the US: Dissecting the "Reversal of Misfortunes". Economic Policy 26(67): 347-385.

Cameron S (1988) The economics of crime deterrence: A survey of theory and evidence. Kyklos 41: 301-323.

Cameron S (1994) A Review of the Econometric Evidence on the Effect of Capital Punishment. Journal of Socio-Economics 23(Issues 1-2): 197-214.

Carr F (1996) The new security politics in Europe. International Journal of the Sociology of Law 24(1): 381-98.

Clark S (2013) Trends in crime and criminal justice, 2010: Statistics in focus. Rep. No. 18/2013, Eurostat.

Cook PJ, Khmilevska N (2005) Cross-national patterns in crime rates. Crime and Justice 33: 331-345.

Cyprus Mail (2018) Turkey and Cyprus back in European court over family's murder. Retrieved from https://bit.ly/2UC4fT5. [Accessed 30 January 2019].

Cyprus Police (2015) Serious crime per category. Retrieved from https://bit.ly/2DSP6Y4. [Accessed 12 February 2015].

Cyprus Police (n.d.) Retrieved from https://bit.ly/2CMpwlL. [Accessed 18 May 2016].

CYSTAT (2014) Cyprus Statistical Service, Criminal Statistics 2011, Report No. 38, Nicosia: Cyprus Government Printing Office. 
CYSTAT (2015) Cyprus Statistical Service, Demographic Report 2014, Report No. 51. Nicosia: Cyprus Government Printing Office.

CYSTAT (2016) Cyprus Statistical Service. Labour Force Survey 2015. Retrieved from https://bit.ly/2DEhkpa. [Accessed 18 Mars 2016].

Dagg P (1991) The psychological sequelae of therapeutic abortion. American Journal of Psychiatry 148(5): 578-85.

Dills AK, Miron JA, Summers G (2008) What do economists know about crime? National Bureau of Economic Research.

Donohue J, Levitt S (2001) Legalized Abortion and Crime. Quarter4 Journal of Economics 116(2): 379-420.

Duggan M (2001) More guns, more crime. Journal of Political Economy 109(5): 10861114.

Eisner M, Killias M (2004) Switzerland. European Journal of Criminology 1(2): 257-293.

Eurostat (2014) Statistical Office of the European Communities, Prison Population. Retrieved from https://bit.ly/2Wrj38N. [Accessed 10 February 2015].

Fazel S, Wolf A, Cheng Z, Larsson H, Goodwin GM, Lichtenstein P (2015) Depression and Violence: A Swedish population study. The Lancet Psychiatry 2(6): 224-232.

Forst B, Filatov V, Klein L (1978) The Deterrent Effect of Capital Punishment: An Assessment of the Estimates. In Deterrence and Incapacitation: Estimating the Effects of Criminal Sanctions on Crime Rates, A Blumstein, D Nagin, J Cohen (eds), 336-60. Washington, D.C.: National Academy of Sciences.

Fox JA, Piquero AR (2003) Deadly demographics: Population characteristics and forecasting homicide trends. Crime and Delinquency 49(3): 339-359.

Goldberger A, Rosenfeld R. (2009) Understanding Crime Trends. Washington. DC: National Academies Press.

Gregoriou P, Kontolemis Z, Matsi M (2010) Immigration in Cyprus: An analysis of the determinants. Cyprus Economic Policy Review 4(1): 63-88.

Gruszczyńska BZ, Heiskanen M (2012) Trends in Police-recorded offences. European Journal on Criminal Policy and Research 18(1): 83-102.

Hadjidemetriou M (1995) Attitudes to the police and policing in contemporary Cyprus with particular reference to the dark figure of crime. $\mathrm{PhD}$ Thesis, Middlesex University, UK.

Hartnagel TF (2009) Correlates of criminal behaviour. In Criminology: A Canadian perspective, R Linden (ed), 137-182. Toronto: Nelson Education Ltd.

Hebenton B, Spencer J (1999) Crime and insecurity in the new Europe: Some observations from Poland. British Society Criminology Conferences: Selected Proceedings, vol. 2.

Hein S, Barbot B, Square A, Chapman J, Foley, Geib C, Grigorenko EL (2017) Violent offending amongst juveniles: A 7-year longitudinal study of recidivism, desistance, and associations with mental health. Law and Human Behavior 41(3): 273-283.

Hinton P (2014) Statistics Explained. $3^{\text {rd }}$ ed. London: Routledge.

ICPC (2010) International Centre for the Prevention of Crime, International Report on Crime Prevention and Community Safety: Trends and Perspectives. Montreal: ICPC

Jolliffe D, Farrington DP, Brunton-Smith I, Loeber R, Ahonen L, Palacios AP (2018) Depression, Anxiety and Delinquency: Results from the Pittsburgh Youth Study. Journal of Criminal Justice. https://doi.org/10.1016/j.jcrimjus.2018.08.004

Jolliffe D, Farrington DP, Loeber R, Pardini D (2016) Protective factors for violence: Results from the Pittsburgh Youth Study. Journal of Criminal Justice 45: 32-40.

Joyce P (2018) Criminology and Criminal Justice: A study guide, $2^{\text {nd }}$ ed. London and New York: Routledge.

Kapardis A (2013) Juvenile delinquency and victimization in Cyprus. European Journal on Criminal Policy and Research 19(2): 171-182. 
Killias M, Wolfgang R (2000) The European sourcebook of crime and criminal justice statistics: a new tool in assessing crime and policy issues in comparative and empirical perspective. European Journal on Criminal Policy and Research 8(1): 312.

Kokkinos M, Kapardis A (2015) Disaggregating tourists in Cyprus by money spent and criminal offending. Journal of Tourism Research 11(1): 64-73.

LaFree G (1999) Declining violent crime rates in the 1990s: Predicting crime booms and busts. Annual Review of Sociology 25(1999): 145-168.

Latzer B (2018) Subcultures of violence and African American crime rates. Journal of

Criminal Justice 54(3): 41-49.

Levitt S (2004) Understanding why crime fell in the 1990s: Four factors that explain the decline and six that do not. Journal of Economic Perspectives 18(1): 163-190.

Marvell T, Moody C (1996) Specification problems, police levels, and crime rates. Criminology 34(4): 609-46.

Mauer M (2003) Comparative International Rates of Incarceration: An Examination of Causes and Trends Presented to the US Commission on Civil Rights. The Sentencing Project.

McCormick S, Peterson-Badali M, Skilling TA (2017) The role of mental health and specific responsivity in juvenile justice rehabilitation. Law and Human Behavior 41(1): 55-67.

Merlo A (2003) Income distribution, police expenditures, and crime: A political economy perspective. Journal of the European Economic Association 1(2-3): 450-458.

Pfeiffer C, Windzio M, Kleimann M (2005) Media use and its impacts on crime perception, sentencing attitudes and crime policy. European Journal of Criminology 2(3): 259-285.

Piquero AR, Jennings WG, Diamond B, Reingle JM (2015) A systematic review of age, sex, ethnicity, and race as predictors of violent recidivism. International Journal of Offender Therapy \& Comparative Criminology 59(1): 5-26.

Raphael S, Winter-Ebmer R (2001) Identifying the Effect of Unemploment on Crime. Journal of Law and Economics 44(1): 259-84.

Sampson RJ, Lauritsen JL (1997) Racial and ethnic disparities in crime and criminal justice in the United States. Crime and Justice 21: 311-374.

Santana P, Santos R, Costa C, Roque N, Loureiro A (2009) Crime and urban environment: Impact on human health. In City Futures in a Globalising World. An international conference on globalism and urban change, 4 to 6 June 2009, Madrid.

Scott M (2014) The Reasoning Criminal, $5^{\text {th }}$ ed. New York: Routledge.

South SJ, Messner SF (2000) Crime and demography: Multiple linkages, reciprocal relations. Annual Review of Sociology 26: 83-106.

Sperling J, Kirchner EJ (1997) Recasting the European order: security architectures and economic cooperation. Manchester: Manchester University Press.

Steffensmeier D, Harer MD (1991) Did crime rates rise or fall during the Reagan presidency? The effects of an "aging" U.S. population on the nation's crime rate. Journal of Research in Crime and Delinquency 28(3): 330-359.

Steffensmeier D, Allan EA, Harer MD, Streifel C (1989) Age and the distribution of crime. American Journal of Sociology 94(4): 803-831.

Stolley KS (1993) Statistics on adoption in the United States. The Future of Children: Adoption 3(1): 26-42.

Tavares C, Thomas G (2010) Crime and Criminal Justice: Statistics in Focus, Rep. No. 58/2010, Eurostat.

Trimikliniotis N (1999) New Migration and Racism in Cyprus: The Racialisation of Migrant Workers. In F Anthias, G Lazarides, Migration and Exclusion in Southern 
Europe (eds), 139-178. Avebury: Ashgate.

Tsiamtsiouri A, Panaretos J (1999) Some statistical analysis of Greek crime data. Report, Athens University, Greece, July.

UN (2005) United Nations, Strategies and best practices for crime prevention, in particular in relation to urban areas and youth at risk. Eleventh United Nations Congress on Crime Prevention and criminal justice, Bangkok, 18-25, April.

Wilson JQ (1985) Thinking about Crime. New York: Random House.

Zalaf A, Wood J (2009) A comparison of attitudes to the police between Greek Cypriots and ethnic minorities living in Cyprus. International Criminal Justice Review 19(4): $381-399$ 